\title{
A America's Failing Trade War With China: A Focus aße on Fentanyl
}

\section{Corinna K. Hamilton}

Dwayne O. Andreas School of Law, Barry University, 6441 E Colonial Dr, Orlando, FL 32807, USA

E-mail for correspondence: hamiltoncorinna@gmail.com

\begin{abstract}
As this article will explain in detail, much of the fentanyl reaching the hands of Americans comes from The People's Republic of China ("China"). However, as seen by the rise in overdoses, most efforts to control the invasion of fentanyl have been unsuccessful. Although the federal and state governments have attempted to curtail this crisis by imposing sanctions and urging China to regulate production and shipping of the substance, fentanyl continues to flood the streets of the U.S. Moreover, the economic interdependence between the two nations complicates the matter. Because of this interdependence, the U.S. must take control of the situation. The U.S. fentanyl problem will persist if Americans are not dissuaded from using the drug. We must focus on the demand, rather than the supply. This comment focuses on the rise of opioids and synthetic pain relievers, and the variety of attempts at decreasing the number of addicts and overdoses. Initially, the comment will discuss history of the popular drug opium, opiates, and prescription opioids, discussing state and federal attempts at curbing the crisis that the U.S. faces. It will address the rise of synthetic opioids, such as fentanyl, and how and why it was created. Section two will discuss how fentanyl and its precursors are imported into the U.S. from China. Section three will discuss U.S. federal and state attempts at legislation to control the flow of fentanyl into the U.S. Section four will address the implications, or perhaps fuel to the fire, that the influx in supply of fentanyl from China has had on trade relations, and how the trade linkage between the two nations obfuscates the situation. The comment will conclude by hypothesizing how the U.S. and China will recalibrate their relationship and recommend that to combat the fentanyl emergency, the U.S. needs to take steps to offer Americans with drug addictions the assistance they need.
\end{abstract}

Keywords: trade, china, us-china relations, fentanyl, opioids, opioid epidemic

\section{INTRODUCTION}

The United States is facing a public health crisis. From May of 2019 to May of 2020, more than 81,000 American people died from an opioid or synthetic opioid overdose, the highest number ever recorded during a twelve-month period. ${ }^{1}$ Fentanyl has played a major part in fueling this crisis, as its use has increased by $38.4 \%$ on average during that time. ${ }^{2}$ The ramifications of this include more than lives lost. In October of 2019, the Council of Economic Advisers

\footnotetext{
${ }^{1}$ Robin Foster, U.S. Drug Overdose Deaths Reach Record Highs, U.S. NEWs (Dec. 17, 2020), https:/ /www.usnews.com/news/healthnews/articles/2020-12-17/us-drug-overdose-deaths-reachrecord-highs.

${ }^{2} I d$.
}

("CEA") estimated "[that the opioid crisis has] cost ... more than $\$ 2.5$ trillion for the four-year period from 2015 to 2018, ... considering the value of lost lives, as well as increases in healthcare and substance abuse treatment costs, increases in criminal justice costs, and reductions in productivity." ${ }^{3}$

As this article will explain in detail, much of the fentanyl reaching the hands of Americans comes from The People's Republic of China ("China"). However, as seen by the rise

\footnotetext{
${ }^{3}$ Council of Economic Advisors, The Full Cost of the Opioid Crisis: \$2.5 Trillion Over Four Years, WHITE HOUSE (Oct. 28, 2019), https: / www.whitehouse.gov/articles/full-cost-opioid-crisis-25-trillion-four-years/.
} 
in overdoses, most efforts to control the invasion of fentanyl have been unsuccessful. Although the federal and state governments have attempted to curtail this crisis by imposing sanctions and urging China to regulate production and shipping of the substance, fentanyl economic interdependence between the two nations complicates the matter. Because of this interdependence, the U.S. must take control of the situation. The U.S. fentanyl problem will persist if Americans are not dissuaded from using the drug. We must focus on the demand, rather than the supply.

This comment focuses on the rise of opioids and synthetic pain relievers, and the variety of attempts at decreasing the number of addicts and overdoses. Initially, the comment will discuss history of the popular drug opium, opiates, and prescription opioids, discussing state and federal attempts at curbing the crisis that the U.S. faces. It will address the rise of synthetic opioids, such as fentanyl, and how and why it was created. Section two will discuss how fentanyl and its precursors are imported into the U.S. from China. Section three will discuss U.S. federal and state attempts at legislation to control the flow of fentanyl into the U.S. Section four will address the implications, or perhaps fuel to the fire, that the influx in supply of fentanyl from China has had on trade relations, and how the trade linkage between the two nations obfuscates the situation. The comment will conclude by hypothesizing how the U.S. and China will recalibrate their relationship and recommend that to combat the fentanyl emergency, the U.S. needs to take steps to offer Americans with drug addictions the assistance they need.

\section{Brief History of the Opioid Epidemic AND the RISE OF SYNTHETIC OPIOIDS}

It is no newsflash that humans have a love affair with mind-altering and pain-relieving substances. Since hunter and gatherer times, humankind has dabbled with plants having psychoactive properties, ranging from coffee beans to hallucinogenic mushrooms. ${ }^{4}$ Humans used plants for a

\footnotetext{
${ }^{4}$ Marc-Antoine Crocq, M.D., Historical and cultural aspects of man's relationship with addictive drugs, 9 DIALOGUES IN CLINICAL NEUROSCIENCE 355, 355-57 (2007).

${ }^{5}$ Id.

${ }^{6}$ Id. at 357

${ }^{7}$ Asbjørn M. Drewes, Rasmus D. Jensen, et al., Differences between opioids: pharmacological, experimental, clinical and economical perspectives, 75 BRITISH JOURNAL OF CLINICAL PHARMACOLOGY 60, 61 (2012).

${ }^{8}$ What is the U.S. Opioid Epidemic?, U.S. DEPARTMENT OF HEALTH AND HUMAN SERVICES (January 2019), https: / /www.hhs.gov/opioids/about-theepidemic/index.html.

${ }^{9}$ Id.

${ }^{10}$ Daniel Kolitz, How Chemists, Chinese Factories, and 'Dark Web' Dealers Spread Fentanyl Across the US, THE NATION (Dec. 20, 2019),
} continues to flood the streets of the U.S. Moreover, the

variety of purposes, including medicinally, religiously and recreationally. ${ }^{5}$ Although "[i]n the course of history, many psychotropic plants have been refined and administered through new routes, allowing faster access to the brain in higher concentrations." 6 Because of the almost instantaneous pain relief it offers, and the recent ease of access, pharmaceutical opioids such as OxyContin, Dilaudid, and Codeine, have gained worldwide popularity. ${ }^{7}$ The increase in use of opioids has given rise to what is now known as the "opioid epidemic" or "opioid crisis" in the U.S. ${ }^{8}$

In early 2019, the U.S. Department of Health and Human Services ("DHHS") reported that this epidemic stemmed from pharmaceutical companies assuring physicians in the early 1990s that prescription opioids were non-addictive and safe to prescribe. ${ }^{9}$ One article published by The Nation went so far as to claim that pharmaceutical companies, such as Purdue, "wooed doctors taught to distrust pain medications with steaks, vacations, and a stunning range of swag: Oxy-branded clocks, pens, beach hats, even swing music compilations." 10 Physicians began to prescribe strong pain relievers to patients with only acute pain, such as sprains or headaches. ${ }^{11}$ It was quickly discovered that the increase in prescriptions of opioids led to an increase in addictions and overdoses. ${ }^{12}$ As it turns out, "[o]piates produce euphoric and tranquil effects when taken in amounts that are larger than prescribed. The pleasant, care-free feelings a person experiences when taking these drugs are often what leads to destructive patterns of abuse." ${ }^{13}$ As a result of careless prescription writing schemes, "[n]early 64,000 Americans died from a drug overdose in 2016 alone. Opioid overdoses accounted for more than 42,000 of these deaths, more than any previous year on record." ${ }^{14}$ This devastation ultimately led to several pharmaceutical executives being criminally convicted and billions of dollars in fines imposed. ${ }^{15} \mathrm{On}$ October 26, 2017, Eric Hargan, acting-Secretary of the DHHS, declared a nationwide public health emergency. ${ }^{16}$

Americans' use of fentanyl, in particular, has spiked in recent years. ${ }^{17}$ In spite of recent attempts at passing federal

https://www.thenation.com/article/archive/fentanyl-increview/.

${ }^{11}$ Mallika L. Mundkur, M.D., Jessica M. Franklin, Ph.D., et al., Days' Supply of Initial Opioid Analgesic Prescriptions and Additional Fills for Acute Pain Conditions Treated in the Primary Care Setting United States, 2014, 68 MORBIDITY AND MORTALITY WEEKLY REPORT 140, 140 (2019).

${ }^{12}$ What is the U.S. Opioid Epidemic?, supra note 8.

13 What Are Opiates?, ADDICTION CENTER (2019), https://www.addictioncenter.com/opiates/.

14 Ending America's Opioid Crisis, THE WhITE HOUSE, https://www.whitehouse.gov/opioids/.

${ }^{15}$ Kolitz, supra note 10.

${ }^{16}$ What is the U.S. Opioid Epidemic?, supra note 8.

${ }^{17}$ German Lopez, How America's opioid epidemic could get even worse, Vox (August 29, 2019 1:00 PM), 
and state legislation to control the opioid crisis, "[o]verdose deaths linked to synthetic opioids, like fentanyl, went up from more than 29,000 in 2017 to nearly 32,000 in 2018. ${ }^{\prime 18}$ It seems that legislative measures came much too late for many American families, especially as it relates to fentanyl. Critics argue that the problem had been debated in Congress for years before anything remotely productive was accomplished. ${ }^{19}$ Ohio Junior Senator, Rob Portman, noted that bringing people together in Congress to get anything done has been difficult, ${ }^{20}$ and Maryland Representative, David Trone, commented that " $\mathrm{t}$ ] he work by Congress has been absolutely dismal, disappointing and ineffective." ${ }^{21}$ In September 2019, Katie Zezima and Colby Itkowitz of the Washington Post wrote:

[i]t took Congress until December 2017 to pass a bill specifically targeting fentanyl - nearly four years after legislators first received warnings about the dangers of the drug. In that time, more than 67,000 Americans had died from overdoses of fentanyl and other synthetic opioids. [Meanwhile, f]entanyl death rates are still rising. ${ }^{22}$

Fentanyl use in the United States is not new; it was approved for use in the 1970s, initially as an anesthetic. ${ }^{23}$ It has been prescribed to terminally ill patients, or those with chronic pain, as its "potency can range from 50 to 100 times that of morphine." ${ }^{24}$ However, fentanyl overdoses are largely attributable to an increase in illicit manufacturing of the drug. ${ }^{25}$ Many times, the user is unaware that the drug being ingested includes fentanyl, as suppliers often mix fentanyl with heroin or cocaine to cut costs and/or increase euphoric effects. ${ }^{26}$ Fentanyl can also be pressed into counterfeit prescription pills, which escalates the risk of overdose, as the user is uninformed of the strength of the drug being taken. ${ }^{27}$ In 2016, fentanyl gained attention in the national news media when it was reported that the singer Prince died from an accidental overdose. ${ }^{28}$

\section{Chinese Production of Fentanyl and Lack of REGULATION}

https:/ / www.vox.com/policy-and-

politics/2019/8/29/20836719/opioid-epidemic-fentanyl-randreport.

${ }^{18} \mathrm{Id}$.

${ }^{19}$ Katie Zezima \& Colby Itkowitz, Flailing on Fentanyl, WASH. POST (Sept. 20 2019),

https://www.washingtonpost.com/graphics/2019/investigatio ns/fentanyl-epidemic-congress/.

${ }^{20} \mathrm{Id}$.

${ }^{21} I d$.

${ }^{22} \mathrm{Id}$.

${ }^{23}$ BRYCE PARDO, JiRKA TAYLOR, et al., THE FUtURE OF FENTANYL AND OTHER SYNTHETIC OPIOIDS 2 (2019).

${ }^{24} I d$.

${ }^{25} I d$.
Of course, as set forth in 21 U.S.C. $§ 952$, it is unlawful to import specified controlled substances into the U.S. ${ }^{29}$ It has, nonetheless, been discovered that "[m]ost of the fentanyl and ... synthetic opioids in U.S. street markets-as well as their precursor chemicals-originate in China, where the regulatory system does not effectively police the country's expansive pharmaceutical and chemical industries." ${ }^{30}$ As a 2017 report from the U.S.-China Economic and Security Review Commission stated:

Chinese law enforcement officials have struggled to adequately regulate the thousands of chemical and pharmaceutical facilities operating legally and illegally in the country, leading to increased production and export of illicit chemicals and drugs. Chinese chemical exporters utilize various methods to covertly ship drugs to the Western hemisphere, including sending illicit materials through a chain of forwarding systems, mislabeling narcotic shipments, and modifying chemicals so they are not controlled in the United States. ${ }^{31}$

Chinese fentanyl became a lucrative substance for American sellers of illicit drugs, as it is approximately 100 times cheaper than Mexican heroin. ${ }^{32}$ In most cases, legitimate pharmaceutical chemicals are diverted by criminals for illicit use due to regulatory loopholes, ${ }^{33}$ sometimes covertly shipped in dog food or bread packaging. ${ }^{34}$

Although China is the world's largest manufacturer of pharmaceutical ingredients, "the country's vast chemical and pharmaceutical industries are weakly regulated and poorly monitored." ${ }^{35}$ Further, China's lack of prioritization in controlling the production and distribution of fentanyl and the substances that are used to create it is largely attributed to the fact that the addiction problem is not apparent in China. ${ }^{36}$

There have been recent attempts in China to pass new regulations to close the loopholes by way of banning certain chemicals and passing stricter licensing

${ }^{26}$ Fentanyl, CENTERS FOR DiseASE CONTROL AND PREVENTION (May 31, 2019),

https:/ / www.cdc.gov/drugoverdose/opioids/fentanyl.html.

${ }^{27}$ PARDO, supra note 23 at 2, 3.

${ }^{28}$ Sean O'Connor, Fentanyl: China's Deadly Export to the United States, U.S.-CHINA ECONOMIC AND SECURITY REVIEW COMMISSION 4 (Feb. 2017).

${ }^{29} 21$ U.S.C. § 952 (2019).

${ }^{30}$ PARDO, supra note 23 at 2, 3 .

${ }^{31} \mathrm{O}^{\prime}$ Connor, supra note 28.

${ }^{32}$ PARDO, supra note 23 at 3.

${ }^{33} \mathrm{O}^{\prime}$ Connor, supra note 28 at 8.

${ }^{34}$ Kolitz, supra note 10.

${ }^{35} \mathrm{O}^{\prime}$ Connor, supra note 28 at 7.

${ }^{36} \mathrm{Id}$. at 5,7 . 
requirements ${ }^{37}$ which is apparently enough to convince some U.S. officials that the Chinese are doing their due diligence. ${ }^{38}$ In September 2019, Reuters reported that "[a] senior White House official ... said he believed China was "absolutely committed" to cooperating with the United States to curb illicit fentanyl." ${ }^{\prime 3}$

Others argue that the attempts by the Chinese government have been largely unsuccessful. ${ }^{40}$ Due to the vast number of production facilities, the Chinese government argues that it has had to narrow its concentration on regulation and enforcement of urban cities, leaving poor rural communities mostly unpoliced..$^{41} \mathrm{I}$ argue that it is more likely that the Chinese government simply turns a blind eye to the production and distribution of fentanyl. The product has to be transported from the rural communities, then to the cities, then to the ports, and then all the way across the ocean, all whilst remaining undetected, which would seem unlikely given the government's ubiquitous use of technology to surveil its citizens. ${ }^{42}$

The Chinese government has demonstrated its ability to crack down on pro-democracy dissidents at a monstrous scale. " ${ }^{43}$ "China] is racing to become the first to implement a pervasive system of algorithmic surveillance. ... purportedly to reduce crime and terrorism. ${ }^{\prime 44}$ The Chinese Communist Party has detained, jailed, required house arrest, and forced into exile, an innumerable number of its citizens for apparent showings of counterrevolutionary propaganda, incitement of subversion to state power, and disturbing public order. ${ }^{45}$ If China were equally concerned about the production and distribution of fentanyl within and from its borders, the situation would be much different today.

Another problem with policing the manufacture of the drug is that it and its precursors can be produced in very

\footnotetext{
${ }^{37} \mathrm{Id}$. at 8 .

${ }^{38}$ Michael Martina \& Ben Blanchard, U.S. official believes China is 'committed' to curbing fentanyl, REUTERS (Sept. 25, 2019 10:39 PM), https:/ /www.reuters.com/article/us-china-usa-drugs/usofficial-believes-china-is-committed-to-curbing-fentanylidUSKBN1WB08A.

${ }^{39} \mathrm{Id}$.

${ }^{40} \mathrm{O}^{\prime}$ Connor, supra note 28 at 8.

${ }^{41} \mathrm{Id}$.

42 Anna Mitchell \& Larry Diamond, China's Surveillance State Should Scare Everyone, THE ATLANTIC (Feb. 2, 2018), China's Surveillance State Should Scare Everyone.

${ }^{43} \mathrm{Id}$.

${ }^{44} \mathrm{Id}$.
}

45 China's voices of dissent, BBC (Aug. 31, 2012), https:/ /www.bbc.com/news/world-asia-pacific-11934996.

${ }^{46}$ Emily Feng, 'We Are Shipping To The U.S.': Inside China's Online Synthetic Drug Networks, NPR (Nov. 17, 2020), https:/ / www.npr.org/2020/11/17/916890880/we-are-

shipping-to-the-u-s-china-s-fentanyl-sellers-find-new-routes-todrug-user. small spaces with rudimentary equipment. ${ }^{46}$ In addition to inadequate or superficial policing, the lack of enforcement also comes from sheer corruption of Chinese government officials, particularly at the local level where public officials are susceptible to bribery from drug manufacturers. ${ }^{47}$ Moreover,

[t]he United States' ability to conduct drug inspections in China has also been obstructed by Chinese regulators, with several recorded instances of Chinese law enforcement and drug regulators delaying visa approvals for FDA officials and deleting laboratory test records. ${ }^{48}$

This allows some chemical manufacturers to knowingly ship their products to the U.S. for illicit purposes without much risk. ${ }^{49}$ As a result of its enormous number of both legal and illegal chemical production facilities, it is no surprise that China's profits from chemical production has consistently increased throughout the years. ${ }^{50}$ Furthermore, "clandestine chemists have with relative ease created new synthetic variations of fentanyl by introducing minor structural modifications, resulting in new, noncontrolled fentanyl-like substances. These substances are specifically engineered to skirt U.S. law." ${ }^{151}$

The Chinese government maintains that U.S. claims of China-sourced opioid shipments are exaggerated ${ }^{52}$ In late August 2019, Liu Yuejin, vice-commissioner of China's Narcotics Control Commission, claimed that "China has tightened the control over fentanyl-related substances, but there are more and more people in the [U.S.] dying from [the drug]. This proves that China is not the main source of fentanyl. ${ }^{\prime \prime 3}$ On November 7, 2019, in a show of purported compliance with U.S. demands, the Chinese government highly publicized the sentencing to death of "[n]ine members of a cross-border fentanyl smuggling ring. ${ }^{\prime 54} \mathrm{It}$

${ }^{47} \mathrm{Id}$.

${ }^{48} \mathrm{Id}$.

${ }^{49} \mathrm{Id}$.

${ }^{50}$ Id. at 7.

51 Andrew Cass, President signs bill extending emergency classification for fentanyl analogs, NEWS-HERALD (Feb. 7, 2020), https:/ / www.news-herald.com/news/president-signs-billextending-emergency-classification-for-fentanylanalogs/article_ecca071c-4940-11ea-832b-f36a43153559.html.

${ }^{52} \mathrm{O}^{\prime}$ Connor, supra note 28 at 8.

${ }^{53}$ Catherine Wong \& Zhuang Pinghui, US fentanyl seizures show China is not the main supplier, Beijing drugs official says, SOUTH CHINA MORNING POST (Sept. 4, 2019 12:36 AM), https://www.scmp.com/news/china/diplomacy/article/30254 80/us-fentanyl-seizures-show-china-not-main-supplier-beijing.

${ }^{54}$ Steven Jiang \& Ben Westcott, China sentences fentanyl drug ring in rare public trial amid US trade talks, CNN (Nov. 7, 2019 10:52 PM), https:/ / www.cnn.com/2019/11/07/asia/china-us-fentanyltrump-hebei-intl-hnk/index.html. 
appears the sentencing of these nine individuals is a show of force to appease the U.S., as the sentencing of nine individuals out of a ring of an incalculable number of manufacturers and distributors is but a drop in the bucket. It could also demonstrate a guilty conscience. Nonetheless, it directly contradicts Liu's claim.

The Chinese government's claims that it is not the main source of fentanyl to the U.S. can be rebutted by evidence of numerous seizures of massive amounts of fentanyl seized by the U.S., Mexico and Canada. ${ }^{55}$ In August of 2019, the Associated Press reported that approximately 66 pounds of fentanyl, which shipped from Shanghai, was intercepted in Virginia - enough to kill fourteen million people ${ }^{56}$ In that same month, Epoch Times reported that the Mexican Navy seized an astonishing 52,000 pounds of fentanyl powder, which also shipped from Shanghai. ${ }^{57}$ Much of what was shipped to Mexico was likely expected to travel across the U.S.-Mexico border by way of cartels. ${ }^{58}$

In light of the aforementioned, the U.S. government has rightfully remained skeptical of China's efforts to curb the inflow of fentanyl and other illicit substances to the U.S. ${ }^{59}$ In August of 2019, President Trump and the White House Administration cited to China's failure to regulate its production and distribution of fentanyl with his decision to impose sanctions and escalate his trade war with the country, ${ }^{60}$ which will be discussed in more detail later in this comment.

Federal and State Legislative Responses to THE OPIOID CRISIS \& INFLUX OF SYNTHETIC OPIOID IMPORTS

\section{A. The United States Postal Service}

The question arises: how does the potent drug get to the U.S. in such large quantities? In August of 2019, the U.S.

${ }^{55}$ US drugs bust uncovers enough Chinese fentanyl 'to kill 14 million people', SOUTH CHINA MORNING POST (Aug. 30, 2019 10:33 PM), https://www.scmp.com/print/news/world/united-statescanada/article/3024993/us-drugs-bust-uncovers-enoughchinese-fentanyl-kill.

${ }^{56} I d$.

${ }^{57}$ Chriss Street, Mexico Seizes 52,000 Pounds of Fentanyl From China, EPOCH TIMES (Aug. 29, 2019), https:/ / www.theepochtimes.com/mexico-seizes-52000-poundsof-fentanyl-from-china_3059981.html.

${ }^{58}$ Ryan Morgan, Mexican Navy seizes 25 tons of fentanyl from China in single raid, AMERICAN MILITARY NEWS (Aug. 27, 2019), https: / americanmilitarynews.com/2019/08/mexican-navyseizes-25-tons-of-fentanyl-from-china-in-single-raid/.

${ }^{59}$ Alan Rappeport, U.S. Puts Sanctions on Chinese Nationals Over Fentanyl Trafficking, NY TIMES (Aug. 21, 2019), https:/ / www.nytimes.com/2019/08/21/us/politics/trumpsanctions-chinese-nationals-fentanyl.html.

${ }^{60} \mathrm{Id}$.

${ }^{61}$ Sari Horwitz \& Scott Higham, The flow of fentanyl: In the mail, over the border, WASH. POST (Aug. 23, 2019), https://www.washingtonpost.com/investigations/2019/08/23
Department of Treasury published a press release in which it confirmed that "[t]he most common distribution medium is via the U.S. Postal Service." ${ }^{61}$ In a Washington Post article on the same subject, the U.S. mail system was identified as a "gaping hole in the nation's borders" that has yet to be fully addressed. ${ }^{62}$ According to the article, private shipping companies, like UPS and FedEx, require all packages to be sent with electronic tracking, allowing packages with suspicious addresses or senders to be intercepted. ${ }^{63}$ On the other hand, approximately 15 percent of packages sent from China are not tracked by the U.S. Postal Service ("USPS"). ${ }^{64}$ In 2019, President Trump ordered that all U.S. mail carriers, including USPS specifically search for and refuse mail deliveries of fentanyl. ${ }^{65}$ The Drug Enforcement Agency ("DEA"), in its 2018 National Drug Threat Assessment, noted that "[f]entanyl sourced from China accounted for 97 percent of fentanyl seized from the international mail" in 2016 and 2017.66

The U.S. Senate Permanent Subcommittee on Investigations ("the Subcommittee") spent a great deal of effort in investigating gaps within the U.S. mail system as it relates to importation of illicit substances. ${ }^{67}$ In its investigation, the Subcommittee took it into their own hands to determine just how easily one can purchase fentanyl from Chinese labs for shipment to the U.S. ${ }^{68}$ Every seller that the Subcommittee encountered preferred to ship via USPS "because the chances of the drugs getting seized were so insignificant that delivery was essentially guaranteed." ${ }^{69}$ In its detailed analysis, the Subcommittee worked with law enforcement agencies and was able to identify some of the major hubs where online transactions originated in the U.S. and bring a few of the U.S. distributors to justice. ${ }^{70}$ Indeed, in 2019, a 29 year old American named Aaron Shamo was sentenced to life in

/ fentanyl-flowed-through-us-postal-service-vehicles-crossingsouthern-border/?arc404=true.

${ }^{62} \mathrm{Id}$.

${ }^{63} \mathrm{Id}$.

${ }^{64} \mathrm{Id}$.

${ }^{65}$ China Is Using Fentanyl as 'Chemical Warfare,' Experts Say, AMAC (Sept. 5, 2019), https://amac.us/china-is-using-fentanyl-aschemical-warfare-experts-say/ [hereinafter "Fentanyl as Chemical Warfare].

${ }^{66} 2018$ National Drug Threat Assessment, U.S. DEP'T OF JUSTICE DRUG ENFORCEMENT ADMIN. (Oct. 2018).

${ }^{67}$ Combatting the Opioid Crisis: Vulnerabilities in International Mail: Hearing Before the Subcomm. on Investigations of the Comm. on Homeland Security and Government Affairs of the U.S. Sen., 115th Cong. 1 (2018) (statement of Sen. Portman, Member, S. Subcomm, on Investigations of the Comm. on Homeland Security and Government Affairs).

${ }^{68} \mathrm{Id}$. at 2 .

${ }^{69} \mathrm{Id}$.

${ }^{70} \mathrm{Id}$. at 3 . 
prison for smuggling fentanyl from China and distributing it across the U.S. via the "dark web." ${ }^{\prime 11}$

However, this small step toward justice was only a BandAid on the Subcommittee's view of the source of the problem: USPS's lack of electronic tracking data. ${ }^{72}$ Senator Rob Portman of Ohio, in his opening statement at the oversight hearing on the topic which took place on January 25,2018 , discussed his dissatisfaction with USPS's failure to collect tracking data and alluded to an abuse of discretion on the part of the Postmaster General and the Treasury Department following the September 11, 2001, terrorist attacks, wherein all other postal services were required to begin tracking all shipments. ${ }^{73}$

In fact, much of the oversight hearing was conducted around the testimony of several individuals regarding the importance of Advanced Electronic Data ("AED") to assist in the tracking of suspicious packages or packages that originate from a foreign country that is known to ship illicit substances. ${ }^{74}$ In his opening statement, Senator Tom Carper of Delaware compared finding fentanyl shipments is much like finding a "needle in a haystack," 75 as the volume of packages that USPS processes "nearly doubled, growing from about 150 million pieces in fiscal 2013 to nearly 500 million pieces in calendar year 2017." ${ }^{76}$ Of course, this poses a giant problem in the ability for any regulation, let alone electronic tracking. Senator Carper pointed to automation of inspections as a potential answer to this ever-growing problem. ${ }^{77}$ When asked to testify as to when an AED program would be fully functioning, however, Joseph Murphy, Chief of International Postal Affairs, could not give a definitive answer. ${ }^{78}$

Finally, in May of 2018, in light of Congress's focus on the issue and despite it being hostile and bi-partisan, a glimmer of hope shined through as the House of Representatives constructed the Synthetics Trafficking and Overdose Prevention Act of 2018, ${ }^{79}$ otherwise known as the

${ }^{71}$ Ellie Bufkin, American gets life sentence for smuggling opioids from
China and using 'dark web' to spread them across US, WASH. POST
(Aug. 31, $32019 \quad 12: 28$ https://www.washingtonexaminer.com/news/american-getslife-sentence-for-smuggling-opioids-from-china-and-using-darkweb-to-spread-them-across-us.

${ }^{72} 2018$ National Drug Threat Assessment, supra note 66.

${ }^{73} \mathrm{Id}$. at 4 .

${ }^{74}$ Id. at $10-22$.

${ }^{75} \mathrm{Id}$. at 7.

${ }^{76} \mathrm{Id}$.

${ }^{77} \mathrm{Id}$.

${ }^{78} \mathrm{Id}$. at $12-13$.

${ }^{79}$ Synthetics Trafficking and Overdose Prevention Act of 2018, H.R. 5788, 115th Cong. (2018) [hereinafter "STOP Act of 2018"].

${ }^{80}$ LORI RECTANUS, U.S. GOV'T ACCOUNTABILITY OFF., GAO-20229R, INTERNATIONAL MAIL: PROGRESS MADE IN USING ELECTRONIC DATA TO DETECT ILLEGAL OPIOID SHIPMENTS, BUT ADDITIONAL STEPS REMAIN 1 (2019).
"STOP Act." ${ }^{80}$ The STOP Act ("the Act") "requires USPS to provide advance electronic data on incoming foreign shipments, including basic information like the name and address of the shipper and recipient. Specifically, the law required USPS to provide this data on 70 percent of all packages mailed from foreign posts, including 100 percent of all packages mailed from China by December 31, 2018." ${ }^{\prime \prime 1}$ The Act was added, adopted, and signed into law as Title VIII of the SUPPORT for Patients and Communities Act on October $24,2018 .^{82}$

Following the enactment of the Act, Congress requested that the U.S. Government Accountability Office ("GAO") complete a study in order to examine:

(1) the extent to which USPS has transmitted required AED for international mail shipments to [U.S. Customs and Border Protection ("CBP")] for use in targeting mail for inspection; (2) any steps USPS and CBP have taken to assess or improve the quality of AED that USPS transmits to CBP; (3) what is known about the costs and benefits of using AED for targeting purposes; and (4) the extent to which USPS has presented targeted international mail to CBP for inspection. ${ }^{83}$

In its report issued on December 18, 2019, the GAO concluded that USPS has not met the transmission standards required by the Act (i.e. at least 70 percent of aggregate mail shipments). ${ }^{84}$ Unfortunately, the report also discussed that the actual transmission rates were not made available to the GAO because USPS considers the data sensitive, ${ }^{85}$ although the CBP claimed that USPS is "presently close to the target goal." 86 The GAO's report also identified that the Department of Homeland Security ("DHS") was to promulgate the Act's regulations, but has failed to do so. ${ }^{87}$ The GAO cited to the DHS's divided attention and red tape as reasons for noncompliance with the Act's requirements. ${ }^{88}$ Senators Portman and Carper

${ }^{81}$ Letter from Sen. Rob Portman \& Sen. Tom Carper to The Hon. Megan Brennen, Postmaster General of the U.S., \& Comm. Kevin McAleenan, U.S. Customs and Border Protection (April 4, 2019) (on file with Senator Tom Carper), https:/ / www.carper.senate.gov/public/index.cfm/2019/4/car per-portman-outline-failure-of-federal-agencies-to-comply-withthe-stop-act [hereinafter "Letter from Sen. Rob Portman \& Sen. Tom Carper"].

${ }^{82}$ SUPPORT for Patients and Communities Act, Pub. L. No. 271, 132 Stat. 3894 (2018) (enacted) [hereinafter "SUPPORT for Patients and Communities Act"].

${ }^{83}$ RECTANUS, supra note 80.

${ }^{84} I d$. at 3 .

${ }^{85}$ Id. n. 7.

${ }^{86} \mathrm{Id}$. at 5 .

${ }^{87}$ Id. at 4 .

${ }^{88} \mathrm{Id}$. 
expressed their dissatisfaction with the progress made in a letter to the Postmaster General, Megan Brennen, and Commissioner of the CBP, Kevin McAleenan, in a letter dated April 4, 2019, stating that the Subcommittee will continue its oversight of, and request for regular briefings from, the USPS, the DHS, and the CBP, in support of their efforts to comply with the requirements set forth by the Act. ${ }^{89}$

The GAO remained hopeful in its report citing several times to the need to establish a time frame for the various government sectors to comply with the Act. ${ }^{90}$ Its report has, however, shown that the headway made by Congress and President Trump was being curtailed by a lack of transparency between overburdened governmental departments and agencies. ${ }^{91}$

\section{B. Federal Legislation}

In response to this public health emergency, the Trump Administration took proactive measures to battle the growing problem since President Trump's inauguration. ${ }^{92}$ The Administration attempted to tackle the supply of legal and illicit opiates, as well as the demand, through several legislative measures, including the Substance UseDisorder Prevention that Promotes Opioid Recovery and Treatment for Patients and Communities Act, or the "SUPPORT for Patients and Communities Act." passed through Congress via Joint Resolution and was signed into law by President Trump on October 24, 2018, and addresses over-prescription of narcotics, provides funding for addicted patients to seek treatment, places certain limits on Medicare and Medicaid recipients, and attempts to regulate the inflow of illicit opiates into the United States. $^{94}$

In early 2018, the DEA, in an emergency effort, temporarily classified all fentanyl analogues, or those chemical compounds substantially similar to fentanyl, as Schedule $\mathrm{I},{ }^{95}$ to make it easier to prosecute cases involving these substances. ${ }^{96}$ This included all illicit fentanyl analogues not already regulated by the Controlled Substances Act. ${ }^{97}$ "The

\footnotetext{
${ }^{89}$ Letter from Sen. Rob Portman \& Sen. Tom Carper, supra note 81.

${ }^{90}$ RECTANUS, supra note 80 at 6.

${ }^{91} \mathrm{Id}$.

${ }^{92}$ Ending America's Opioid Crisis, supra note 14.

${ }^{93} \mathrm{Id}$.

${ }^{94}$ SUPPORT for Patients and Communities Act, supra note 82.

${ }^{95}$ Schedules of Controlled Substances: Temporary Placement of Fentanyl Related Substances in Schedule I, 83 Fed. Reg. 25, 518891 (Feb. 6, 2018).

${ }^{96}$ Michael Collins, Criminal Justice Reform in the Fentanyl Era: One Step Forward, DRUG POLICY Alliance (Jan. 2020), https://www.drugpolicy.org/sites/default/files/dpa-cjreform-fentanyl-era-v.3_0.pdf.

${ }^{97}$ U.S. Drug Enforcement Administration Emergency Schedules All Illicit Fentanyls In An Effort To Reduce Overdose Deaths, U.S. DRUG ENFORCEMENT AGENCY (Feb. 7, 2018),
}

bill won the approval of Senators as a short-term compromise after several unsuccessful attempts at amending the Controlled Substances Act to permanently schedule fentanyl analogues." ${ }^{\prime 98}$ Schedule I is the category for substances with no currently accepted medical use, ${ }^{99}$ including cocaine and heroin. ${ }^{100}$ This emergency classification was valid for two years, with the possibility of a one-year extension. ${ }^{101}$ The bill for extending the classification for fifteen additional months was signed into law by President Trump on February 6, 2020, the day it was set to expire. ${ }^{102}$ The extension is valid until May 6, 2021. ${ }^{103}$

In the fashion of this day and age, there is political disagreement over how the DEA should be handling fentanyl analogues and how much the government should be involved. ${ }^{104}$

Opponents of a long-term Schedule I classification — like the ACLU, Drug Policy Alliance and NAACP - argued the approach "merely repeats the mistakes of the past by exacerbating our incarceration problem."

"The committee should move away from the belief that increased enforcement powers for the DEA will translate into reduced overdose deaths," a coalition of opposing organizations to a Senate committee last year. "Instead, the committee should embrace public health approaches to the overdose crisis."

Other concerns from opponents include concern that the classification would make it harder for researchers to win approval to study the analogues to potentially develop new approaches to fighting the opioid epidemic. ${ }^{105}$

The ACLU, the Drug Policy Alliance and the NAACP aren't wrong. Drug Policy Alliance ("DAP"), a New York City-based non-profit organization dedicated to ending the American "War on Drugs," ${ }^{106}$ proposes that the criminalization approach to combating addiction is "punitive[,] ... far exceed[s] what is necessary to maintain

https:/ / www.dea.gov/press-releases/2018/02/07/us-drugenforcement-administration-emergency-schedules-all-illicit [hereinafter "DEA Press Release"].

${ }^{98}$ Nathan Yerby, U.S. Senate Temporarily Extends Schedule I Status for Fentanyl Analogues, ADDICTION CENTER (Jan. 31, 2020), https://www.addictioncenter.com/news/2020/01/u-s-senateextends-schedule-i-fentanyl-analogues/.

${ }^{99}$ DEA Press Release, supra note 97.

${ }^{100}$ Cass, supra note 51.

${ }^{101}$ DEA Press Release, supra note 92.

${ }^{102}$ Cass, supra note 51.

${ }^{103} \mathrm{Id}$.

${ }^{104} I d$.

${ }^{105} \mathrm{Id}$.

106 About Us, Drug Policy Alliance, https: / / www.drugpolicy.org/about-us. 
public safety and primarily target[s] poor people and people of color." ${ }^{107}$ The DAP highlights that "the Trump administration ... reported in May of 2019 that there has been a 40-fold increase in federal fentanyl-related prosecutions during the President's time in the White House. ${ }^{\prime 108}$ In its report demonstrating support for healthcentered addiction control, titled Criminal Justice Reform in the Fentanyl Era: One Step Forward, Two Steps Back, the DPA discusses the contradictory approaches of some lawmakers. ${ }^{109}$ Some legislators who have supported the scaling-back of drug related incarcerations have now turned to harsher sentences for fentanyl related crimes, thereby challenging reforms in the U.S. criminal justice system. ${ }^{110}$ In the report's conclusion, there is a call for consistency in drug enforcement: "We cannot talk about 'treatment, not incarceration' and then revert to interdiction and enforcement when a new substance that frightens us appears on the scene."111

\section{State Legislation}

States have also taken initiatives to curb America's problem with opiates and opioids. ${ }^{112}$ For example, in 2018, the Florida legislature adopted House Bill 21, which limits physicians to providing a three-day supply of prescription narcotics to patients with acute pain, as well as requires physicians to consult with the Prescription Drug Monitoring Program database before prescribing certain medications, in order to prevent "doctor shopping." ${ }^{\text {"13 }}$ As of August 14, 2018, Florida was one among approximately two dozen states to pass similar laws, which "serve to reduce opioid prescription." ${ }^{114}$

Some researchers are skeptical that legislation such as Florida's House Bill 21 will actually curb the number of overdoses and deaths arising from opioid abuse. ${ }^{115}$ "While the prescription opioids are to blame for the onset of the

${ }^{107}$ Mass Incarceration and Criminalization, DRUG POLICY ALLIANCE, https:/ /www.drugpolicy.org/issues/mass-criminalization.

${ }^{108}$ Collins, supra note 96.

${ }^{109} \mathrm{Id}$.

${ }^{110} \mathrm{Id}$.

${ }^{111} \mathrm{Id}$.

${ }^{112} \mathrm{Id}$.

${ }^{113}$ H.B. 21, 120th Reg. Sess. (Fla. 2018).

${ }^{114}$ Naseem Miller, Florida's new opioid law: What you need to know, ORLANDO SENTINEL (Aug. 14, 2018, 6:00 AM), https:/ / www.orlandosentinel.com/health/os-florida-opioidbill-doctors-20180803-story.html.

${ }^{115}$ Id.

${ }^{116} I d$.

117 Opiate Addiction and Abuse, ADDICTION CENTER (2019), https://www.addictioncenter.com/opiates/.

${ }^{118}$ Pradip K. Muhuri, Joseph C. Gfroerer \& M. Christine Davies, Associations of Nonmedical Pain Reliever Use and Initiation of Heroin Use in the United States, CENTER FOR BeHAVIORAL HeAlth $\begin{array}{llll}\text { STATISTICS AND } & \text { QUALITY }\end{array}$ epidemic, the main driver of overdose deaths today is illicit opioids, including heroin, fentanyl and the deadly carfentanyl..." ${ }^{116}$ With legal routes for obtaining painrelieving drugs limited, and because of their reduced costs, many users have turned to illicit drugs that mimic the effects of opioids. ${ }^{117}$ Research from The Substance Abuse and Mental Health Services Administration indicates that approximately " 80 percent of people who use heroin first misused prescription opioids." ${ }^{118}$

Other states have taken different approaches to dealing with the consequences of addiction. ${ }^{119}$ In late 2017, thenfront runner for District Attorney of Pennsylvania, Larry Kasner, announced his support for supervised injection sites, ${ }^{120}$ "a place for people in addiction to use drugs under medical supervision, and be revived if they overdose." ${ }^{121}$ In early 2018, the city of Philadelphia became the first to announce its support for these sites, ${ }^{122}$ from a seemingly desperate place. Philadelphia's Health Commissioner, Thomas Farley, pled "[t]he people in the city of Philadelphia, our brothers, our sisters, our parents, our children, are dying. And they don't need to die. And we have an obligation to do everything we can to prevent those people from dying."123

Of course, this effort was not without its opponents. Many players in the U.S. government adamantly are opposed to supervised injection sites. ${ }^{124}$ In October of 2018, the U.S. Surgeon General, Jerome Adams, expressed that he was skeptical about these sites. ${ }^{125}$ Then in February of 2019, “U.S. Attorney William M. McSwain file[d] suit in federal court to block the opening of a supervised injection site, citing a 1986 law — known colloquially as the 'crack-house statute' - that makes it a felony to knowingly open or maintain any place for the purpose of manufacturing, distributing, or using controlled substances." ${ }^{126}$ McSwain's strong stance on this topic is that "[n]ormalizing the use of

https://www.samhsa.gov/data/sites/default/files/DR006/DR 006/nonmedical-pain-reliever-use-2013.htm.

${ }^{119}$ Joseph A. Gambardello, Philadelphia's supervised injection site has faced a long legal battle: How we got here, PHILADELPHIA INQUIRER (Feb. 26, 2020), https://www.inquirer.com/health/opioidaddiction/supervised-injection-site-philadelphia-safehousecourt-timeline-20200226.html.

${ }^{120} \mathrm{Id}$.

${ }^{121}$ Aubrey Whelan \& Anna Orso, Supervised injection site in South Philadelphia will not open - at least for now, PHILADELPHIA INQUIRER (Feb. 27, 2020), https://www.inquirer.com/news/supervised-injection-sitesouth-philadelphia-mcswain-appeal-rendell-20200227.html.

${ }^{122}$ Gambardello, supra note 119.

${ }^{123} \mathrm{Id}$.

${ }^{124}$ Id.

${ }^{125} \mathrm{Id}$.

${ }^{126}$ Id. 
deadly drugs like heroin and fentanyl is not the answer to solving the opioid epidemic." ${ }^{127}$ The issue of whether these sites violate the crack-house statute was litigated for months before the district judge ruled that the sites do not violate the statute, in that "the ultimate goal of [the] proposed operation is to reduce drug use, not facilitate it." ${ }^{\prime 28}$ Although there was a positive ruling in court, at the time of this writing the opening of the sites is still a work in progress due to community resistance. ${ }^{129}$

\section{The Role of Fentanyl in President Trump's U.S.-CHINA TRADE WAR}

\section{A. Timeline}

In 2010, China soared to the top, becoming the world's second largest economy after the U.S. ${ }^{130}$ with speculators predicting that it would soon be number one. ${ }^{131}$ Although there is a strong argument that President Obama began pushing back against Chinese trade practices by filing a complaint at the World Trade Organization ("WTO") in 2012, ${ }^{132}$ President Trump carried the baton even further. With economic competition apparent, Donald Trump, in his 2016 presidential campaign, expressed his concern with several U.S. trade deals, claiming unfair trade practices, and promising to impose sanctions and tariffs on China. ${ }^{133}$ President Trump immediately began trade negotiations with China's General Secretary Xi Jinping in 2017, which ultimately failed, leading to U.S. imposition of tariffs on certain imported goods, such as washing machines, solar panels, steel and aluminum. ${ }^{134}$ In response, China retaliated and imposed tariffs on U.S. products, including soybeans and airplanes. ${ }^{135}$ In mid-2018, negotiators drafted a large and convoluted trade agreement that was ultimately discarded and tariff imposition resumed by both countries. ${ }^{136}$ These tit-for-tat responses by each

\footnotetext{
${ }^{127} \mathrm{Id}$.

${ }^{128} \mathrm{Id}$.

${ }^{129}$ Whelan \& Orso, supra note 121.

${ }^{130}$ David Barboza, China Passes Japan as Second-Largest Economy, NY TIMES (Aug. 15, 2010), http:/ / archive.nytimes.com/www.nytimes.com/2010/08/16/b usiness/global/16yuan.html.

${ }^{131}$ Stephen Johnson, China will overtake the U.S. as world's top economy in 2020, says Standard Chartered Bank, BIG THINK (Jan. 14, 2019), https://bigthink.com/politics-current-affairs/chinaworlds-biggest-economy-2020.

${ }^{132}$ Larry Elliot, Obama takes on China with formal trade complaint over auto subsidies, THE GUARDIAN (Sept. 17, 2012), https:/ / www.theguardian.com/business/2012/sep/17/obamachina-trade-war-wto.

${ }^{133}$ Timeline: Key dates in the U.S.-China trade war, REUTERS (Jan 15, 2020), https://www.reuters.com/article/us-usa-trade-chinatimeline/timeline-key-dates-in-the-u-s-china-trade-waridUSKBN1ZE1AA [hereinafter "Timeline"].

${ }^{134} I d$.

${ }^{135} \mathrm{Id}$.

${ }^{136} \mathrm{Id}$.
}

respective country continued through 2018, until a 90-day halt on tariffs was agreed to by both parties on December $1,2018 .{ }^{137}$

This back-and-forth came to a head in August of 2019, when China halted purchases of U.S. agricultural products, ${ }^{138}$ some of the U.S.'s largest exported products to China. ${ }^{139}$ This pushed the U.S. to take the trade talks more seriously and begin negotiations again, leading to an agreement on a Phase One Trade Deal between the two nations titled the Economic and Trade Agreement Between the Government of the United States of American and the Government of the People's Republic of China ("Phase One"). ${ }^{140}$ Phase One focuses particularly on China's commitment to import more U.S. goods and pledge to protect U.S. intellectual property. ${ }^{141}$ However, the deal left many issues unaddressed, including talks of further fentanyl regulation. In July of 2020, President Trump indicated he was disinterested in participating in further discussions with China, and that a "phase two" deal was off the table due to China's poor handling of the COVID19 pandemic. ${ }^{142}$

\section{B. The Drug War Fueling the Trade War}

There have been many publicized discussions about President Trump's passion for ending the fentanyl crisis in the U.S. leading to harsher tariffs imposed on Chinese goods. ${ }^{143}$ After one meeting in 2017 with China's leader, Xi Jinping, President Trump indicated that he and his Chinese counterpart would "be focusing on [fentanyl] very strongly." ${ }^{144}$ Then in late 2018 at the G20 Buenos Aires summit, President Trump seemingly got what he asked for: $\mathrm{Xi}$ "agreed to designate fentanyl as a controlled

\footnotetext{
${ }^{137} I d$.

${ }^{138} I d$.

${ }^{139}$ The People's Republic of China, OfFICE OF THE U.S. TRADE REP., https:/ / ustr.gov/countries-regions/china-mongoliataiwan/peoples-republic-china.

${ }^{140}$ Timeline, supra note 133.

${ }^{141}$ Helen Raleigh, The Phase One U.S.-China Trade Deal Is A Serious Win For The United States, FEDERALIST (Jan. 24, 2020), https://thefederalist.com/2020/01/24/the-phase-one-u-s-chinatrade-deal-is-a-serious-win-for-the-united-states /.

${ }^{142}$ Kevin Breuninger, Trump says U.S.-China relationship is 'severely damaged,' phase 2 trade deal not a priority, CNBC (Jul. 10, 2020), https:/ / www.cnbc.com/2020/07/10/trump-says-us-chinarelationship-damaged-phase-2-trade-deal-not-a-priority.html.

${ }^{143}$ Jeff Mordock, Fentanyl flows from China despite Trump trade war, Xi crackdown vow, WASH. TIMES (Sept. 24, 2019), https://www.washingtontimes.com/news/2019/sep/24/fenta nyl-flows-china-despite-trump-trade-war-xi-cr/.

${ }^{144}$ Sui-Lee Wee \& Javier C. Hernández, Despite Trump's Pleas, China's Online Opioid Bazaar Is Booming, NY TIMES (Nov. 8, 2017), https:/ / www.nytimes.com/2017/11/08/world/asia/chinaopioid-trump.html.
} 
substance..."145 and China did just that approximately six months later. ${ }^{146}$ China claimed it "expanded ... the list of narcotics subject to state control to include the more than 1,400 known fentanyl analogues, which have slightly different chemical makeups, but are all addictive and potentially deadly, as well as any new ones developed in the future." ${ }^{147}$ Notwithstanding this development, "Chinese vendors have tapped into online networks [including Facebook and Alibaba] to brazenly market fentanyl analogs and the precursor chemicals used to make fentanyl, and ship them directly to customers in the U.S. and Europe as well as to Mexican cartels..." ${ }^{148}$ As NPR reported in November of 2020, these vendors are often using code names, and acronyms, engage in direct trade through the Internet, and are protected by a complex system of corporate entities, making enforcement against them more difficult. ${ }^{149}$

Moreover, “[i]n an August 23[, 2019] tweet, U.S. President Donald Trump accused the Chinese General Secretary of not doing enough to stop the flow of synthetic opioids into the U.S." ${ }^{\prime 150}$ A Washington Times article went so far as to claim that the Trump administration was punishing China for its "failure to get tough on fentanyl through [the President's] trade war." ${ }^{151}$ Liu Yuegin accused the U.S. of politicizing the fentanyl issue, twisting facts, and claiming that actions, such as placing sanctions on and freezing the assets of Chinese fentanyl producers, is harming the two counties' relationship. ${ }^{152}$

This is not the first instance wherein allegations of drugdealing has been used to fuel a trade war, or military incursion. ${ }^{153}$ The writing is on the wall. The Chinese

${ }^{145}$ Steven Lee Myers, China Cracks Down on Fentanyl. But Is It Enough to End the U.S. Epidemic?, NY TIMES (Dec. 1, 2019), https:/ /www.nytimes.com/2019/12/01/world/asia/chinafentanyl-crackdown.html.

${ }^{146} I d$.

${ }^{147}$ Jonathan Landay, Trump accuses China's Xi of failing to halt fentanyl exports to U.S., REUTERS (Aug. 2, 2019), https:/ / www.reuters.com/article/us-usa-china-

fentanyl/trump-accuses-chinas-xi-of-failing-to-halt-fentanylexports-to-u-s-idUSKCN1US1WI.

${ }^{148}$ Feng, supra note 46.

${ }^{149} \mathrm{Id}$.

150 Bertil Lintner \& Chiang Mai, The drug war behind the trade war, ASIA TIMES (Nov. 10, 2019), https:/ / www.asiatimes.com/2019/11/article/the-drug-warbehind-the-trade-war/.

${ }^{151}$ Mordock, supra note 138.

${ }^{152}$ China accuses US of using fentanyl as a political weapon as Donald Trump orders shipping firms to step up checks, S. CHINA MORNING Post (Aug. 24, $2019 \quad 3: 06 \quad$ PM), https://www.scmp.com/news/china/diplomacy/article/30242 07/china-accuses-us-using-fentanyl-political-weapon-donaldtrump.

${ }^{153}$ Lintner \& Mai, supra note 150. government has not forgotten its rich history, claiming a "century of humiliation" when the First and Second Opium Wars were "fought over Western forces' demand for better trade terms and access to Chinese markets," advancing Western and Japanese colonialism of the country. ${ }^{154}$ This included the trade of opium from Britain to China to improve their trade balance. ${ }^{155}$ There is irony in the fact that the tables have turned and China is now the country pushing the drugs. Of course, this can be no excuse for negligent policies relating to the production and trade of deathly substances.

\section{U.S.-China Economic Interdependence}

Some argue that President Trump, through his trade practices, is putting relations with China into a "Cold Warlike deep freeze,"156 and the two countries could be facing a Thucydides trap: a term coined by American political scientist Graham T. Allison to describe an apparent tendency towards war when an emerging power threatens to displace an existing great power as the international hegemon. ${ }^{157}$ In a 2015 article (notably before President Trump's inauguration), Allison predicted that war with China is "more likely than not," ${ }^{158}$ citing a study conducted at Harvard, which concluded that in twelve of sixteen similar cases over the past 500 years, war resulted. ${ }^{159}$

Of course, we must ask ourselves if these trade discussions are doing enough, or anything at all, to advance the interests of the U.S., as full on military war with China's 2.5 million soldiers and growing military budget, ${ }^{160}$ is not a favored outcome. This is evidenced by President Trump's recent executive order claiming a national emergency and

154 Alice Su, As trade war escalates, Chinese remember 'national humiliation,' LOS ANGELES TIMES (May 13, 2019), https:/ / www.latimes.com/world/la-fg-china-trade-war-tariffscolonialism-humiliation-20190513-story.html.

155 Key Facts of the Opium Wars, BRITANNICA (2021), https://www.britannica.com/summary/Key-Facts-of-the-

Opium-Wars.

${ }^{156}$ Azhar Sukri, From trade to TikTok: How US-China decoupling affects everyone, ALJAZEERA (Aug. 4, 2020), https:/ / www.aljazeera.com/economy/2020/8/4/from-tradeto-tiktok-how-us-china-decoupling-affects-everyone.

${ }^{157}$ Jeremy Cliffe, US-China economic integration shaped today's world, but now it is going into reverse, NEWSTATESMAN (Oct. 19, 2020), https://www.newstatesman.com/world/2020/10/us-chinaeconomic-integration-shaped-today-s-world-now-it-goingreverse.

${ }^{158}$ Graham Allison, The Thucydides Trap: Are the U.S. and China Headed for War?, THE ATLANTIC (Sept. 24, 2015), https://www.theatlantic.com/international/archive/2015/09/ united-states-china-war-thucydides-trap/406756/.

${ }^{159} \mathrm{Id}$.

${ }^{160}$ Benjamin Brimelow, China's military has become one of the world's most powerful, but the US still has one big advantage, BUSINESS INSIDER (Jul. 13, 2020), https:/ / www.businessinsider.com/chinese-military-isimproving-but-us-has-more-combat-experience-2020-7. 
banning U.S. investments in certain blacklisted Chinese military companies. ${ }^{161}$ The executive order reasoned that,

...the People's Republic of China (PRC) is increasingly exploiting United States capital to resource and to enable the development and modernization of its military, intelligence, and other security apparatuses, which continues to allow the PRC to directly threaten the United States homeland and United States forces overseas, including by developing and deploying weapons of mass destruction, advanced conventional weapons, and malicious cyber-enabled actions against the United States and its people. ${ }^{162}$

This makes clear that the U.S. government sees China as a military threat, and some experts even argue that China is using fentanyl as a chemical weapon. ${ }^{163}$

A trade war with China, however, is unsustainable. ${ }^{164}$ Although "President Trump has repeatedly raised the possibility of divorcing the U.S. and Chinese economies," 165 it cannot be ignored that the U.S. and China are the world's two largest economies and each other's' largest trading partners. ${ }^{166}$ "The United States and China don't just coexist. Their massive economies are deeply intertwined in ways that make the intensifying trade war unsustainable." 167 Among those reasons are the Chinese's love of and need for American products, from brands like Nike and Apple. ${ }^{168}$ Further, American companies rely on inexpensive labor and parts from the Chinese, which has inextricably bound the two countries through supplychain linkages. ${ }^{169}$ Even more importantly, China is the U.S.'s largest creditor and plays a huge role in financing the U.S.'s increasing debt. ${ }^{170}$

Given all of these reasons, there are those that argue that the normalization of diplomatic relations and trade

${ }^{161}$ Trump bolsters ban on U.S. investments in China, REUTERS (Jan. 13, 2021), https://www.reuters.com/article/us-usa-trump-chinainvestments / trump-bolsters-ban-on-u-s-investments-in-chinaidUSKBN29J04J.

${ }^{162}$ Exec. Order No. 13,959, 85 Fed. Reg. 73185 (2020), as amended in F.R. _ (2021).

${ }^{163}$ Fentanyl as Chemical Warfare, supra note 65.

${ }^{164} \mathrm{Id}$.

165 Yen Nee Lee, 5 charts show how much the U.S. and Chinese economies depend on each other, CNBC (Sept. 28, 2020), https://www.cnbc.com/2020/09/29/5-charts-show-how-theus-and-chinese-economies-depend-on-each-other.html.

166 Matt Egan, Why the US-China trade war won't last, CNN BUSINESS (May 14, 2019), https:/ / www.cnn.com/2019/05/14/business/china-unitedstates-economy-trade-war/index.html.

${ }^{167} \mathrm{Id}$.

${ }^{168} \mathrm{Id}$.

${ }^{169} I d$.

${ }^{170} I d$. between the U.S. and China has resulted in mutual benefit. ${ }^{171}$ China has moved away from labor-intensive industries, and its "total imports and exports of goods increased 223-fold" over the past four decades. ${ }^{172}$ At the same time, the U.S. has experienced a 90 percent increase of its gross domestic product over that same period, which is still six times that of China's. ${ }^{173}$ "While the [U.S.] may want to bring some manufacturing back from overseas, the blunt severing of trade ties via executive orders is shortsighted and self-defeating ... [and when the two countries] are at odds, they both lose out on opportunities to expand their respective economies and turn over those chances at growth to other counties looking to get ahead." 174 This is elaborated by the fact that some nations, such as India, Indonesia and Turkey, feel no need to align themselves with either the U.S. or China, as it is more beneficial for them to see the two countries face off. ${ }^{175}$

\section{RECOMMENDATION}

Perhaps the U.S. government should take time to do some self-reflection, as the number of those struggling with addiction issues has risen despite all of the state and federal efforts to curb the inflow of illicit drugs and their precursor chemicals. ${ }^{176}$ It has become clear over the past decade that these attempts have been fruitless. At each turn, Chinese chemical manufacturers adapt and respond. Where there is a demand, China will be there to provide the necessary supply.

In 2016, the DHHS, along with the Surgeon General, published a Report on Alcohol, Drugs, and Health. ${ }^{177}$ The report pointed to a number of domestic reasons for the increase in substance abuse: stressful work and home environments, inability to obtain appropriate healthcare, over-prescription of opioids, ineffective prevention and treatment programs, criminal justice issues, and many more. ${ }^{178}$ The Report concludes by calling "to all Americans

\footnotetext{
${ }^{171}$ Peter Reisman, 40 Years of US-China Relations Have Been Good for the US, INT'L BANKER (Sept. 1, 2020), https:/ /internationalbanker.com/finance/40-years-of-us-chinarelations-have-been-good-for-the-us/.

${ }^{172} \mathrm{Id}$.

${ }^{173} \mathrm{Id}$.

${ }^{174} \mathrm{Id}$.

${ }^{175}$ Hal Brands \& Zack Cooper, The Great Game with China is 3D Chess, FOREIGN POLICY (Dec. 30, 2020), https:/ / foreignpolicy.com/2020/12/30/china-united-statesgreat-game-cold-war/.

${ }^{176}$ American Drug Use is on the Rise, UNITY BEHAVIORAL HEALTH (2018), https://www.unityrehab.com/blog/american-drug-usetrend-on-the-rise/.

177 Facing Addiction in America: The Surgeon General's Report on Alcohol, Drugs, and Health, U.S. DEP'T OF HEALTH \& HuMAN SvCS. 1 (2016), https: / / www.ncbi.nlm.nih.gov/books/NBK424857/pdf/Books helf_NBK424857.pdf.

${ }^{178}$ Id. at 1-1, 1-14, 1-18, 6-4.
} 
to change the way we address substance misuse and substance use disorders in our society," ${ }^{179}$ and begin looking at substance abuse as a health concern, rather than a criminal one ${ }^{180}$ - one where we are looking inwards for guidance, rather than placing blame on others; one where we seek to control the demand and not the supply. ${ }^{181}$ The U.S. cannot count on other nations to fix the problems within its borders.

With a new White House Administration settling in, it is possible that this inward reflection takes place. President Joseph Biden, in his campaign, stated that he has long recognized substance abuse disorders as diseases, rather than lifestyle choices, and that he "will tackle this crisis by making sure people have access to high quality health care - including substance use disorder treatment and mental health services." ${ }^{182}$ His plan describes investing $\$ 75$ billion in grants to states and localities for prevention, treatment and recovery efforts, including Medication Assisted Treatment ("MAT") available to all who need it by $2025 .{ }^{183}$ While his campaign also promised to stem the flow of the drugs from places like China and Mexico, ${ }^{184}$ the best way forward is to attack the problem at its root: addiction.

Of course, this does not mean that the U.S. should take a back seat and let China do whatever they please. Contrary to expectations based on alleged dealings that President Biden and his son, Hunter, had in the past with Chinese firms, ${ }^{185}$ "the Biden administration is already projecting a tougher policy on China ... than many expected," and that he may continue the same hard stance against China as his predecessor. ${ }^{186}$ So far, there have been no "precipitous actions" taken with regard to the trade policies and Trump tariffs remain in place, while the administration conducts "an intense consultation and review." ${ }^{187}$ In his first call with $\mathrm{Xi}_{\mathrm{i}}$ Jinping since taking office, Biden raised his concerns about human rights abuses occurring in China, and a dialogue opened up between the two leaders. ${ }^{188}$
Biden discussed that he will go about China relations in a different way than President Trump, and has created a Defense Department task force to review U.S. military policies toward China. ${ }^{189}$ With all of the deeply rooted tensions and issues to unravel, we must hope that the fentanyl crisis remains on President Biden's list of priorities.

\section{CONCLUSION}

Faced with the reality of the web that both the U.S. and China are entangled, relations are likely to normalize. Of course, the tension runs deeper than manufacturing jobs and IP theft - it is a struggle for control between two great economic powers. With a choice between a Cold War-like situation, full on military war (as predicted by Graham T. Allison in his Thucydides trap theory), or stabilizing trade through diplomatic relations, the two countries are likely to choose the latter outcome. Too much is at stake. The mutual benefits derived from trade amongst the countries, the inevitable disruption in the supply-chain for companies all over the globe, and U.S. attempts at maintaining economic control over China, are all likely reasons for the relationship to steady.

This, however, could mean that some parts of the negotiations are forgotten, or simply discarded, in order to keep the peace. Regulation of the production and importation of fentanyl and fentanyl precursors, for example, is likely to be seen as a small price to pay for the U.S. in its attempts to keep China from rising to a global superpower. Of course, this would mean that fentanyl will continue to come into the hands of Americans, and hundreds of thousands will continue to die from overdoses.

$$
--0-
$$

\footnotetext{
${ }^{179} \mathrm{Id}$. at 7-16.

${ }^{180}$ William R. Kelly, Ph.D., The Drug Problem in the U.S. Is Not What We Think It Is, Psychology TODAY (Sept. 26, 2018), https://www.psychologytoday.com/us/blog/crime-andpunishment / 201809 / the-drug-problem-in-the-us-is-not-whatwe-think-it-is.

${ }^{181}$ Id.

182 The Biden Plan to End the Opioid Crisis, BIDEN HARRIS, https://joebiden.com/opioidcrisis/.

${ }^{183} \mathrm{Id}$.

${ }^{184} I d$.

${ }^{185}$ Hunter Biden: What was he doing in Ukraine and China?, BBC (Dec. 10, 2020), https:/ /www.bbc.com/news/world-54553132.
}

\footnotetext{
${ }^{186}$ John Ruwitch, Inside The Biden Administration's Policy On China And Taiwan, NPR (Feb. 5, 2021), https:/ / www.npr.org/2021/02/05/964581463/inside-thebiden-administrations-policy-on-china-and-taiwan.

${ }^{187}$ Brooke Singman, Biden spoke with Chinese President Xi Jinping for the first time since taking office, FOX NEWS (Feb. 11, 2021), https://www.foxnews.com/politics/biden-in-first-call-with-xijinping-outlines-us-china-policy-core-concerns-of-chinas-abuses.

${ }^{188}$ Michael Crowley, Biden Raises Concerns With China's Xi in First Call Since Election, N.Y. TIMES (Feb. 10, 2021), https://www.nytimes.com/2021/02/10/us/politics/biden-xijinping-call.html.

${ }^{189} I d$.
} 